HStud 28 (2014)2, 211-234 DOI: 10.1556/HStud.28.2014.2.2

\title{
IMAGES OF THE FRIENDSHIP WITH BARTÓK: FROM BÉLA BALÁZS'S RECOLLECTIONS
}

\author{
YOSHIKO OKAMOTO \\ The University of Tokyo, Tokyo \\ Japan \\ E-mail: okamotosy@gmail.com
}

\begin{abstract}
Béla Balázs, the librettist of Béla Bartók's Bluebeard's Castle and Wooden Prince, wrote many remarks about Bartók in his recollections throughout his life, and their manuscripts are preserved in Budapest, in the Library of the Hungarian Academy of Sciences and National Széchényi Library. Some parts of these texts, however, still remain unpublished. Even though his reminiscence tends to exaggerate their friendship, which in fact ended in their earliest period in Budapest, examination of the sources provides us with a new understanding of the relationship between the librettist and the composer. Therefore, this paper introduces the documents written by Balázs, gives a selective overview of their friendship, and examines how the image of Bartók changed in Balázs's mind over time.
\end{abstract}

Keywords: Béla Balázs, Béla Bartók, Hungarian literature, music, Bluebeard's Castle, Wooden Prince, stage works, recollection, exile

\section{Introduction}

As several previous studies have mentioned, a vast number of manuscripts and typewritten scripts by Hungarian playwright and film critic Béla Balázs still remain unpublished. ${ }^{1}$ Hungarian resources are mainly preserved in Budapest in the Library of the Hungarian Academy of Sciences Manuscript Collection (MS 5009-5024) ${ }^{2}$ and the Manuscript Collection of National Széchényi Library (Fond 134). ${ }^{3}$ The latter collection, which has not been researched minutely, includes the manuscripts of his recollections about Hungarian composer Béla Bartók.

Balázs and Bartók had a relationship not only as the composer and the librettist of the opera Bluebeard's Castle and the ballet Wooden Prince, but also as neighbors and friends in the 1910s in Budapest. However, since Balázs defected from Hungary to Vienna after the collapse of the Hungarian Soviet Republic (1919), their relationship became one-sided, with Balázs seeking Bartók's friendship. Consequently, no more collaboration was realized in the end.

This short-term friendship has been viewed rather skeptically in Bartók's studies because of the fact that Bartók did not mention him at all in his career; for in- 
stance, Demény stated that Balázs's role should not be overestimated; Bartók did not mention Balázs not because of political reasons, for Bartók was not afraid of dedicating his composition to another refugee, Béla Reinitz, in spite of the political situation in Hungary at that time. ${ }^{4}$ Mentioning that today "we can only conjecture", Leafstedt also points out that "this was one of those friendships that grew too burdensome emotionally for one of the parties, who then, without any sense of malice and without conscious effort, simply began to find the company of other people preferable". 5

On the other hand, however, their friendship was a beautiful memory that was to be glorified and romanticized for Balázs. What is overlooked is that it is impossible to deal with their interactions equally before and after Balázs's exile, which decisively brought distance between them and urged Balázs to start writing recollections and autobiographies. Moreover, for Balázs in exile, it seems that publicly writing many recollections and articles about Bartók in Hungarian, whose name became well known in Western Europe, was an important political as well as personal act of going back to the root of his youth and Hungarian modernism, to which he had once devoted himself. Therefore, these articles need to be considered as autobiographical works by Balázs rather than "primary resources" about Bartók or other historical events.

Hence, this paper deals with the images of Bartók created by Balázs. Comparing portraits of Bartók in Balázs's diary with his reminiscence, the transition and changing images of a composer described by a writer will be examined. The materials are Balázs's diary from 1904 to 1922 and several recollections, including the aforementioned unpublished resources. Analyzing these texts, I attempt to discuss the signification of changing images and memories and their relation with cultural as well as political background. As a consequence, this paper tends to focus on Balázs's works and texts about Bartók rather than their stage works and their processes of creations, although as a matter of course, this stance does not deny the fact that re-examining these texts still provides us with several new facts about the relationship between the composer and the librettist.

The contents of the article are as follows: the first part gives an overview of their relation in the 1910s and collaboration. The second part shows the catalog of articles about Bartók written by Balázs. In the third part, several depictions from the diaries and the recollections (both in exile and after Bartók's death) are compared and analyzed. 


\section{The Relationship between Bartók and Balázs: Chronology and Collaboration}

Balázs wrote several autobiographical novels, Impossible People (Unmögliche Menschen) (1930) and Dreaming Youth (Álmódó ifjúság) (1946), and these works are frequently cited in biographies. ${ }^{6}$ However, compared with his diaries it seems that these autobiographical works include more misconceptions and some exaggerations. ${ }^{7}$ This section attempts to briefly describe the relationship between Bartók and Balázs based on real-time resources such as letters and diaries as much as possible. Table 1 shows their collaborative works, including unrealized plans. It indicates there were at least three collaborative works planned during their lives; one was just a suggestion and one was created after Bartók's death.

Although it is uncertain exactly when and where he got acquainted with Bartók, in 1906 he had already participated in collecting folksongs with Bartók in Szeged, Balázs's hometown. It is very plausible that Zoltán Kodály, Balázs's roommate of Eötvös Collegium, connected them. Balázs's entry on 1906 depicts Bartók who he had just encountered. ${ }^{8}$

After that, there are no traces that they met or discussed for about three years probably because of Balázs's absence in Budapest in 1906-07, when he gained a scholarship and stayed in Vienna, Paris, and Berlin. After his return to Budapest, they lived in the same building "Teréz ringstreet 17" near Oktogon, which is the intersection in Pest side (see Figure 1). ${ }^{9}$ Bartók's residence was number 23 and Balázs's number 26 on the same $4^{\text {th }}$ floor (European Style). The letters and their envelopes clearly show that they lived in that building at the least from January to September in $1910 .{ }^{10}$ Moreover, according to the fact that postmarks stamped in post office number 62 (near Oktogon) did not change it is relatively possible that they lived there, visiting each other, until Bartók's family moved to Rákoskeresztúr in May 1911.

It was this year when Bartók composed his first collaborative work with Balázs, one-act opera Bluebeard's Castle based on the cognominal drama. This symbolist opera unfortunately failed twice in opera competitions. However, Balázs's letter to Bartók in early 1912 implies that they already planned their next collaborative work, called "groteszque pantomime", which probably would become ballet Wooden Prince. ${ }^{11}$ The libretto was published in Nyugat in 1912, and in the next year they made a contract with the Royal Hungarian Opera. ${ }^{12}$ Around the same period, another stage work project was also planned by Balázs, a fairy tale drama entitled Ilona, a Smiling Fairy. ${ }^{13}$ Balázs asked Endre Ady, one of the most influential poets at that time, to versify his fairy tale and Bartók to set music to it. Nevertheless, his fascinating plan turned out to be fruitless because Ady did not work out. ${ }^{14}$ 


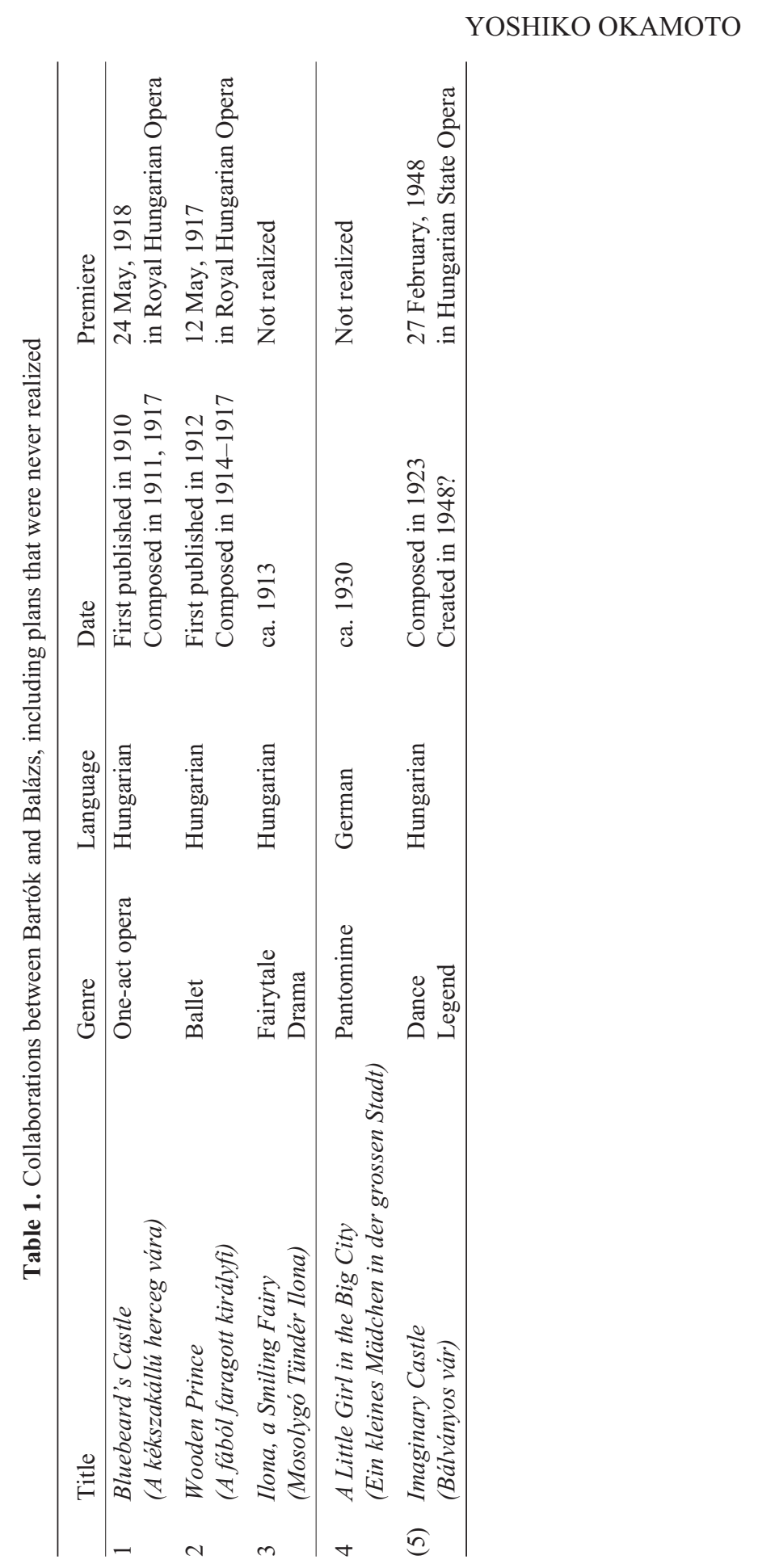




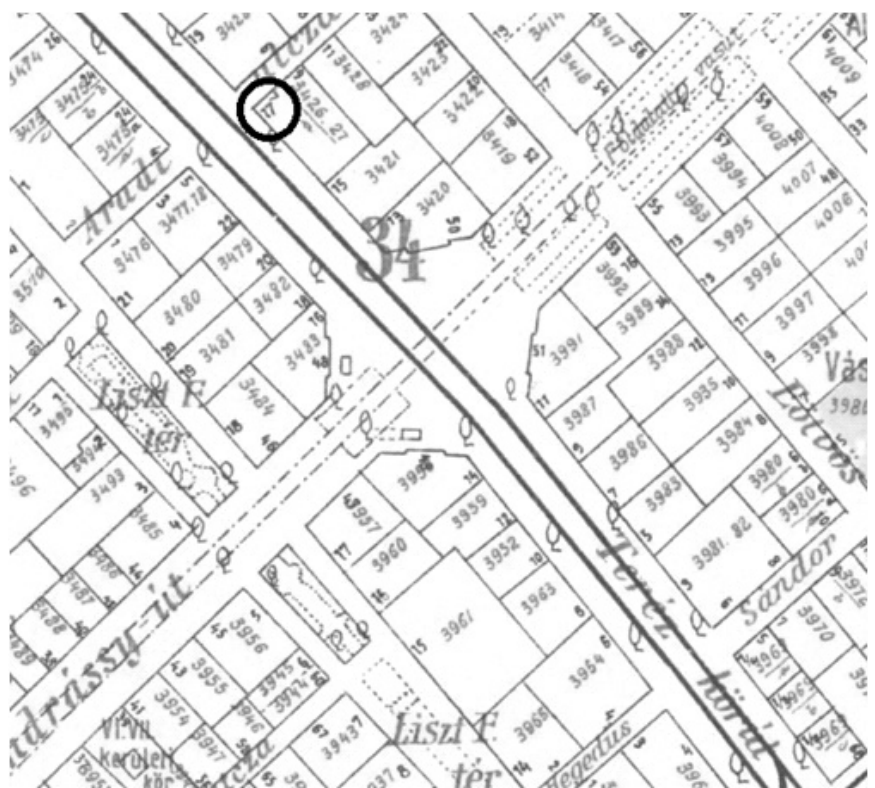

Figure 1. The Location of the Residences of Bartók and Balázs (Teréz ringstreet, 17) Budapest székesfőváros területének térképe 1:5000 (Budapest: Budapest Székesfőváros Mérnöki Hivatala, Budapest Székesfőváros Tanácsa, 1908), 34.

Budapest History Museum, Kiscelli Museum

The outbreak of World War I forced young Hungarian intellectuals to return to their homeland. Balázs and Lukács held a philosophical circle called "Sunday Circle" with some of those philosophers, and according to Emma Litoók, Kodály and Bartók sometimes dropped in to join this circle. Although few real-time documents of the activities of this circle remain, documents of the lecture series "Lectures from Intellectual Circle" carried out by them mention that Kodály and Bartók also participated (or at least were going to participate) in this series as a lecturer. ${ }^{15}$ In 1917, The Wooden Prince was finally performed preceding Bluebeard's Castle in the Royal Hungarian Opera House. This successful performance led the opera to the stage in the next year as well. Finally, Bartók came to be recognized as a talented composer, but these performances did not satisfy Balázs, for the media valued Bartók's music but blamed his librettos. ${ }^{16}$

It is said that both Bartók and Balázs took part in the lower organization of the Commissariat of Public Education in Hungarian Soviet Republic to a greater or lesser extent, ${ }^{17}$ which was established after October Revolution and Communist Revolution and ended in demise a mere 133 days later. In December 1919, Balázs escaped from the White Terror by Horthy regime to Vienna. After that demise, with the exception of several letters, they did not seem to contact each other. Nevertheless, one letter shows that Balázs suggested that Bartók create one more stage 
work with him, presumably a pantomime titled A Small Girl in a Big City written in German. Balázs wrote this plan and sent it from Berlin when Bartók had asked to resign his royalty of their stage works Bluebeard's Castle and Wooden Prince in Hungary. ${ }^{18}$ However, it did not stimulate Bartók to compose. Somfai, Zsuffa and Lenkei noted that this plan was never realized probably because of its scandalous plot. ${ }^{19}$ After the long exile in Vienna, Berlin, and Moscow, Balázs came back to Hungary and Ballet Imaginary Castle was created in 1948 with Bartók's Dance Suite, Balázs's libretto and Gyula Harangozó's choreography. Of course, it was not a bona fide collaboration, as it was produced after Bartók died in New York in 1945.

The interactions between Bartók and Balázs, therefore, lasted almost only in the 1910s and they produced only two works together. This relationship and collaboration were just small parts of their careers for both of them. Still, Balázs "linked Bartók to wider cultural circles", ${ }^{20}$ as Hooker states, and no doubt that Bartók entered his name into this intercultural - and left-wing intellectual - group. The result of these influences was one of Bartók's most radical articles "On Hungarian Music" in Aurora (1911), presumably his participation in the New Hungarian Music Society ${ }^{21}$ and the participation in the lecture series of Sunday Circle, eventually in the Hungarian Soviet Republic.

The end of World War I and a number of exiles made this flexible community discrete, and Bartók and Balázs had no further interaction. There were two plausible reasons: one is that Balázs began to be dissatisfied with his treatment while Bartók became more and more famous as composer; the other is the distance because of Balázs's political emigration. In this situation, Balázs started to write recollections publicly, which consequently involved not only personal activity, but also had political nuances.

\section{Sources and Recollections about Bartók Written by Balázs}

Balázs indeed wrote various kinds of texts about Bartók. These writings include diaries, newspaper and magazine articles, and public letters. Table 2 shows these recollections, critical essays, and other resources and works.

As aforementioned, Balázs kept his minute diary from 1904 to 1922, which is used as a primary resource for studies of Balázs. He wrote about personal events and his relationships as well as his creations of dramas or poetries. However, compared with Kodály, with whom Balázs had close relationship, fewer entries or personal depictions of Bartók are noted than entries related to business or complaints about their collaborative works.

Bartók first appears in the entry of September $5^{\text {th }} 1906$. As discussed later, this describes Bartók's appearance and his impression when Bartók and Kodály 
stayed in Szeged, which is Balázs's hometown, and Balázs also accompanied them to collect folksongs. On September $7^{\text {th }}$ in 1911, Balázs also mentioned that he spent that summer with Bartók and admired his talent and individuality. In other entries, Balázs tended to write about collaborations and their premiers. In July 1913, Balázs recollected Bluebeard's Castle's premier as a drama, in which Bartók also participated in playing the piano in the intermission and Balázs persuaded Bartók to contract with Royal Opera House as for Wooden Prince. Between 1917 and 1918, he intensively wrote about their premiers in the opera house; especially about Wooden Prince in detail because according to him, he took part in the stage production.

After his demise, Balázs mentioned Bartók several times in 1921 and 1922. These entries are almost complaints that Bartók did not evaluate Balázs's achievement for him. They did not meet each other directly, and it seems that his situation as a refugee made it more and more difficult to assess the political condition in Hungary. Conversely, the opera house abandoned their credit of Balázs as a librettist in the production. It was in that period when Balázs started to write his recollections about Bartók, who became more and more known as a composer both in Hungary and Western Europe.

Balázs's earliest reminiscence seems to be lost. According to his diary, he contributed an article to a feature issue on Bartók in a music magazine Musikbätter des Anbruch in 1921, which was not published in the end. ${ }^{22}$ The next year, he published another article titled "Diary" in Hungarian Newspaper in Vienna. This newspaper is the Hungarian daily paper that appeared in 1919 in Vienna, and Balázs often contributed to it.

In Moscow, the form of "Diary" written in Vienna became that of "Letter". A Hungarian magazine New Voice was published in 1938, and Balázs contributed one article titled "Letters from a Distance to Bartók" (Levelek a távolból. Bartók Bélának küldöm) in 1938. Although it was not clear where it was published, he wrote another public letter in 1941 called "From a Distant Land, to a Distant Land: On the Occasion of Béla Bartók’s Sixtieth Birthday (Messziről messzire: Bartók Béla hatvanadik születésnapjára)".

After Bartók's death in 1945, Balázs intensively recollected Bartók again in Hungary. Balázs was already in Budapest at that time, and he provided an article for commemoration for Bartók in the theater magazine Light Beam (Fényszóró) that he edited (Figure 2). The last recollection was published in 1948 in Forum, and its title was "Indivisible Man".

There are other types of writings as well. Balázs hardly wrote reviews or critical essays about Bartók's compositions. The only plausibly essay is "Béla Bartók's Folksiness", which appeared in 1946 in Forum. It might be also noteworthy that Balázs attained inspiration from Bartók in his literary works. The 


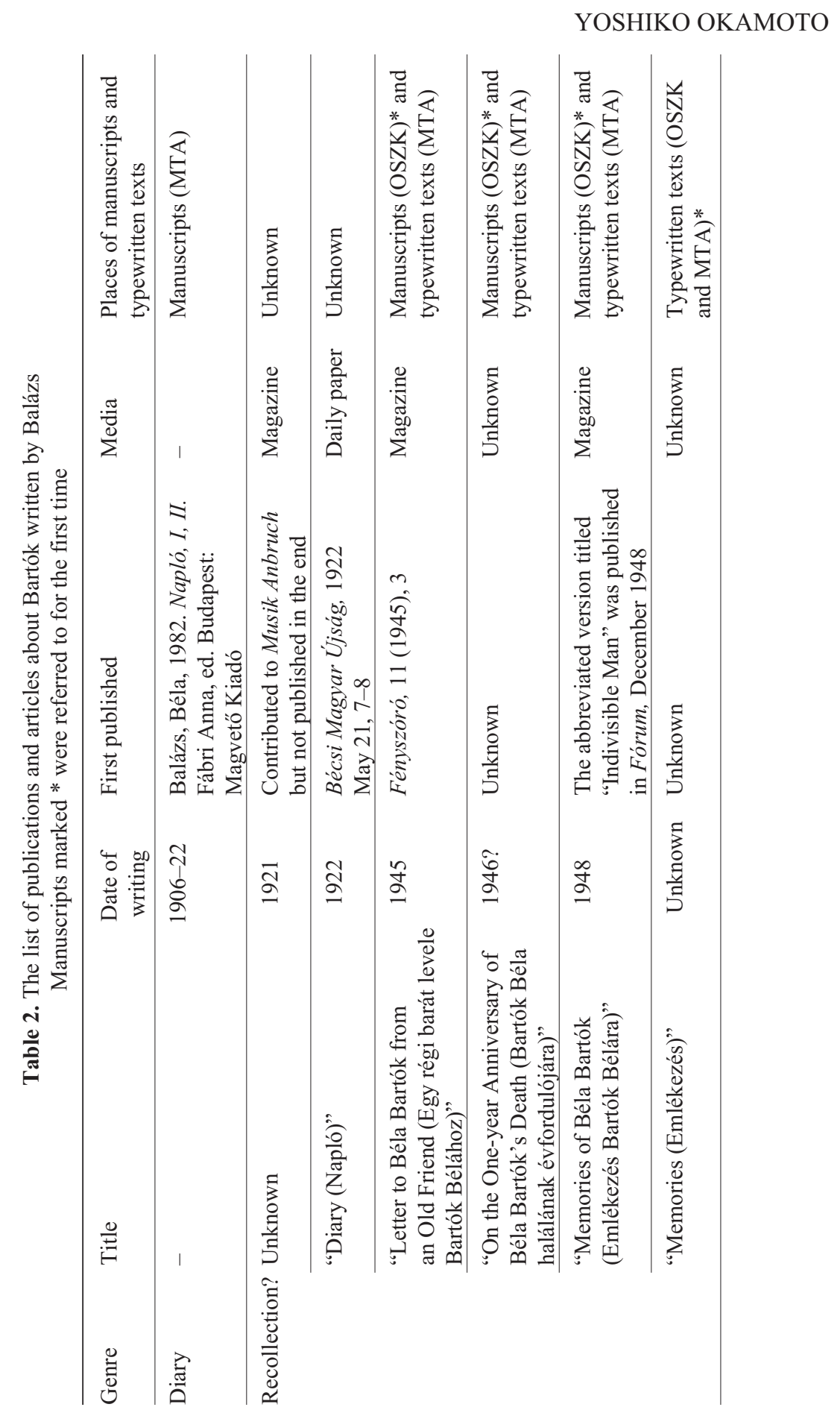




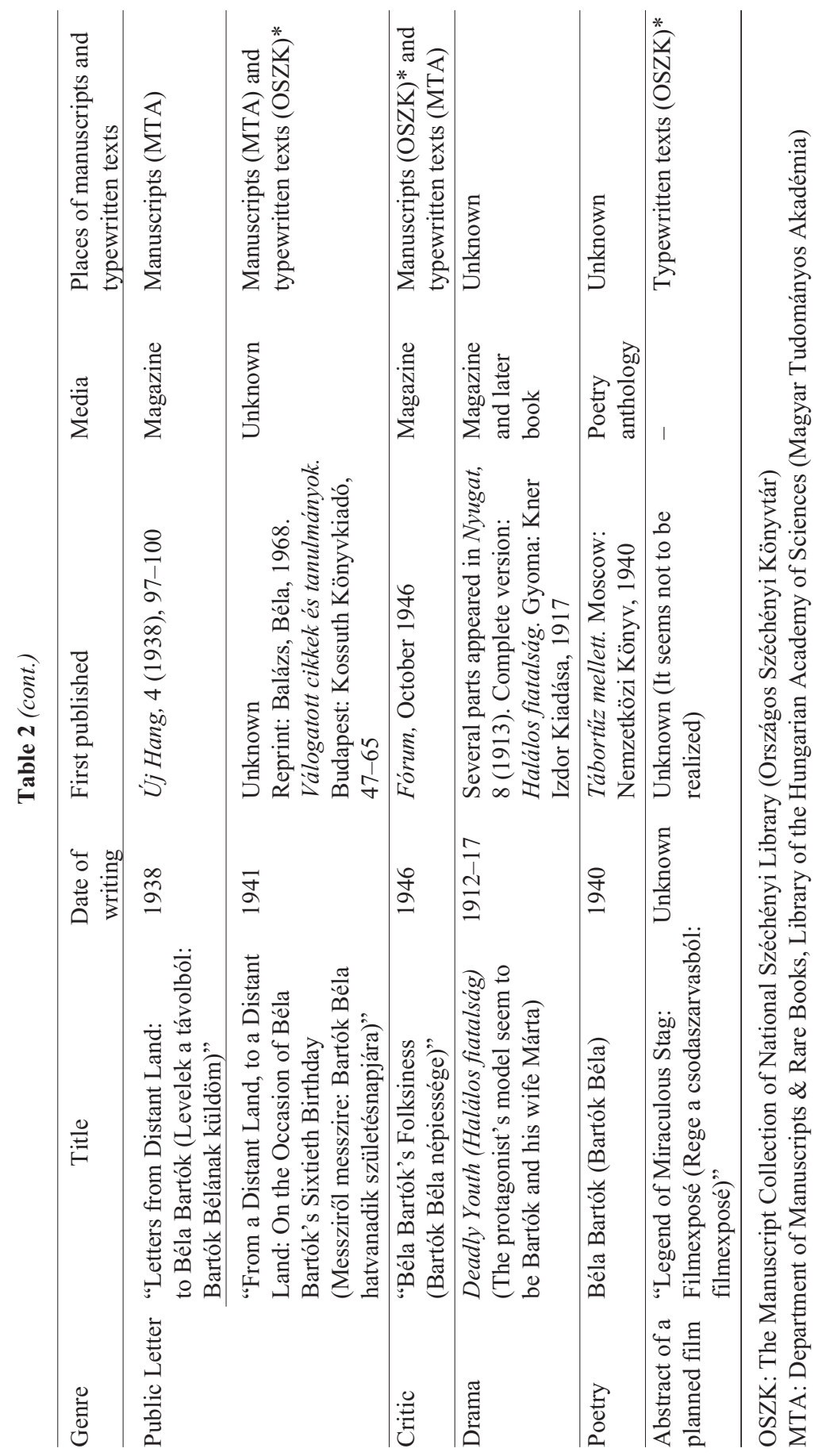




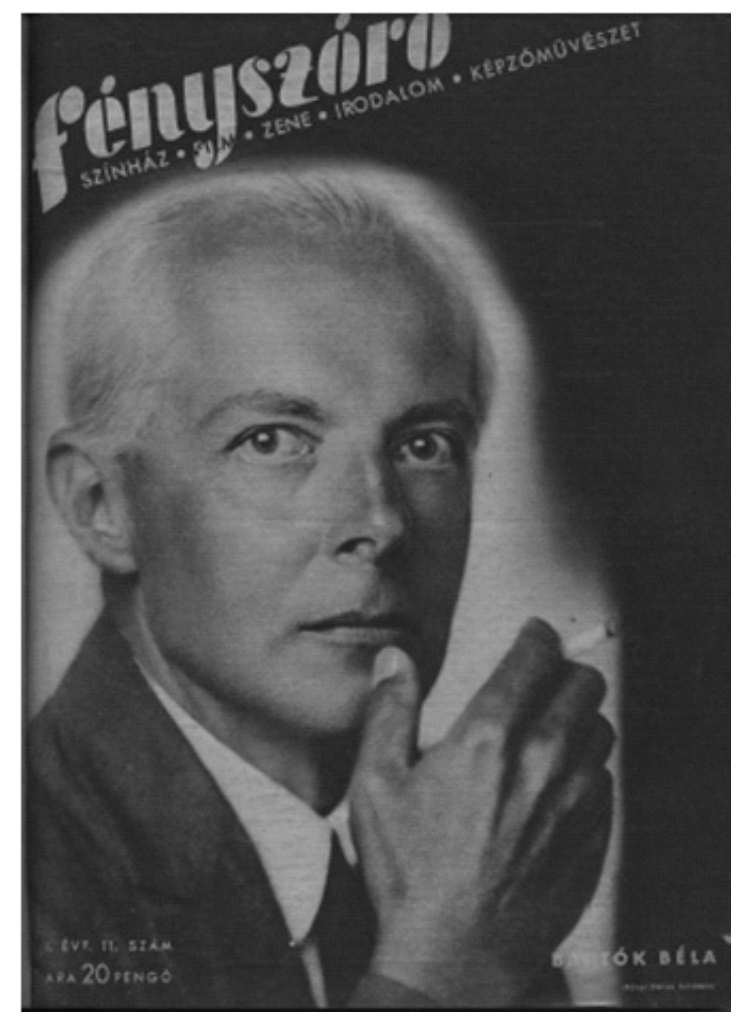

Figure 2. The Front Cover of Bartók Issue of Fényszóró, vol. 1, no. 11, October $3^{\text {rd }}, 1945$ http://epa.oszk.hu/01900/01982/00011/pdf/fenyszoro_1945_11.pdf (Accessed: May 4 ${ }^{\text {th }}, 2013$ )

protagonists of a drama Deadly Youth published in 1917 probably derived from Bartók and his wife. Moreover, he wrote a poem titled Bartók as well as Mozart and Michelangelo, in which he admired Bartók's individuality and excellence in 1940. In this way, Bartók gave Balázs inspirations for creations and writing recollections.

\section{The Changing Friendship between Librettist and Composer: The "Summoned" and Created Image of Bartók}

This section discusses the transition that took place in the images of Bartók, citing and analyzing Balázs's texts. The materials are his diaries written in the period in which they could actually meet each other in Budapest, the "Diary" that appeared in Hungarian Newspaper in Vienna and the public letter in 1938 in Moscow, and finally the last recollection from "Memories of Béla Bartók", which was the draft 
of Indivisible Man preserved in the National Széchényi Library and the Library of Hungarian Academy of Sciences.

\section{Depiction in the Diaries}

As mentioned in the previous section, Balázs's diary includes the depictions of Bartók. Although there is a blank between the years of 1906 and 1911, it gives a basic impression of Bartók when Balázs could meet him in Hungary. According to this, his strong characteristic was "Wunderkind".

Szeptember 5.

Itt volt Bartók Béla, egy hétig együtt jártunk népdalt gyűjteni. Naiv, esetlen. Egy 25 (vagy hány) eves csodagyerek. Csudálatos, csendes szívósság van benne. [...] Gyönyörüen játszik, szép dolgokat ír. Nem értek hozzá, de az emberből nem éreztem ki a nagyot. [...] Gyereknaivitással, kiváncsiságból kutakodik.

Csillagászkodik, bogarász, etnografizál stb. Ez a mohósága nyilván abból magyarázandó, hogy a zenén kívül nem sok egyebet tanult idáig. [...] És a zenéjén kívül semmit se tudok belőle élvezni.

$$
\text { [1906], September } 5^{\text {th }}
$$

Béla Bartók was here. We spent a week collecting folksongs together. He is naive and awkward. A twenty-five-or-odd-year-old Wunderkind. And yet there exists in him an incredibly quiet tenacity. [...] He plays splendidly and writes beautiful works. I don't know much about him, but from his personality I don't feel greatness. [...] He researches with childish naiveness and curiosity.

He skygazes, he is also entomologist and acts like an ethnographer etc. This eagerness can be clearly explained by the fact that except for music, he has not learned much more. [...] And outside of his music, I am able to enjoy nothing about him. ${ }^{23}$

Firenze [1911], szept. 7.

$[\ldots]$

Annál jobban megszerettem Bartók Bélát. A legmeghatóbb ember. [...] Hihetetlen, varázsos méltóság és előkelőség van benne. [...] És mennyi gyermekesség, mennyi báj van benne. [...] Valami csodálatos paradoxia van a megjelenésében. Alakja, arca, mozgása olyan, mint egy rokokó hercegé, és mégis valami titanikus méltóság van rajta. Egy rokokó titan! Egy 32 éves, véres komolyságú csodagyermek. $[\ldots]$ 
I am becoming all the more fond of Béla Bartók. He is the most moving and most marvelous man. [...] He has unbelievable, magical dignity and nobility. [...] And how much childishness, how much charm exists within him. [...] There is some wonderful paradox in his appearance. His figure, face, demeanor are those of a Rococo prince and yet he possesses some titanic dignity. A Rococo titan! A 32-year-old Wunderkind in deadly earnest. $[\ldots]^{24}$

Particularly the depictions in the former such as "from his personality I don't feel greatness" or "outside of his music, I am able to enjoy nothing about him" show that Balázs's first impression of Bartók was that of an innocent and childish man depreciated, except for music. This is probably because of his comparison with Kodály, one of the intellectuals who had just graduated from the Pázmány Péter University and attained a doctoral degree. As for collecting folksongs, Bartók was still a beginner in this field. The latter recollection describes that Balázs came to like Bartók and the sense of depreciation had already disappeared. Nonetheless, his attention tended to focus rather on personal activities and Bartók's hobbies than on music. Although Balázs publicly mentioned Bartók and Kodály and highly valued them, ${ }^{25}$ his personal diary dealt with their personality and their relationships with Balázs, which makes it clear that he was less interested in their compositions.

\section{Recollections in Exile: "Public" Diary and Letter}

Other entries in his diary are almost complaints about the production of the stage works. As Demény stated, it is possible that Balázs referred to his diaries when recollecting Bartók. It was the sense of loneliness and frustration that urged Balázs to make these emotions public.

On May $21^{\text {st }}$ in 1922, Balázs published an article titled "Diary" in Vienna, just after the premiers of Bluebeard's Castle and Wooden Prince on May $14^{\text {th }}$ in Frankfurt, Germany. The texts mainly include his memories about collecting folksongs near Tisza river in 1906, the creation of the two stage works, and the premier of Wooden Prince. Here Balázs emphasized his achievements and contributions to their works and attempted to confess private emotions in his diary.

És én voltam, én az emigráns forradalmár, akkor, aki hitet élesztettem benne. Én beszéltem neki a nagy magyar kultur-renaissanceról, a magyarság hivatásáról az európai kultúra fejlődésében, [...] Azt akartam, amit Bartók. Együtt akartuk egy fiatalságban. Hittük, hogy 


\begin{abstract}
az egészen ujat csak az egészen régiből lehet kipalántázni, hogy csak az ősmatéria birja el a mi spiritualizálásunkat ugy, hogy mégsem párolog el az ujjaink között.

I [Balázs] was, I was the emigrant revolutionist, who stirred his belief in him [Bartók]. It was I who talked to him about the Hungarian great cultural renaissance, the call of Hungary in the development of European culture, [...] I wanted the same as Bartók. We wanted it together in our youth. In our belief, complete novelty could be derived only from what was ancient, since only primeval material could be expected to stand our spiritualization without evaporating from under our fingers. ${ }^{26}$
\end{abstract}

He explains that after the failure of Bluebeard's Castle, it was Balázs who persuaded Bartók not to leave the country and to compose another stage work. For Balázs, Bartók is still comrade of the Hungarian modernist movement. We cannot know whether these memories are true or not, but at least we can imagine how Balázs cherished his youth and activities in Hungary.

Moreover, it is noteworthy that he wrote about not only private events, but also very political affairs. This is the most significant difference from his private diary. When its chief editor was a socialist Oszkár Jászi from 1920 to 1923 and Balázs contributed, Jászi wanted Hungarian Newspaper in Vienna to function as the hub of activities of Hungarian exiles in Vienna. ${ }^{27}$ Therefore, it is natural that an article tends to be opposed to Horthy's regime in Hungary: just a recollection of Bartók also includes a political tone that denounces the situation in Hungary. The object of criticism is not only the regime, but also Bartók himself. Here Balázs produces an image of Bartók, who was such an innocent artist that he still stayed in Budapest - this depiction reminds us of the tone in his diary in 1906 - enjoying his privileged position, being entertained by Horthy.

[...] És máma Bartók Béla Horthynál teázik. Ezt senki se vegye rossz néven tőle. Bartók nem politikus és nyilván nem is tudja, hogy ez mit jelent. [...]

Én most, hogy Bartók Béla a nemzetközi zenetudomány tárgya lett, bizvást elbucsuzhatom tőle. Mert én csak költő vagyok. Engem, mint irót, mégis csak az ember érdekel és az ő embersége.

[...] And today Béla Bartók has a cup of tea with Horthy. Forbid that anyone not take it badly. He is not a politician and he doesn't absolutely know what it means. [...]

Now, when Béla Bartók has become the object for studies of international musicological studies, I surely could bid a farewell to him. Because I am just a poet. Just a man, his personality interests me, as a poet. ${ }^{28}$ 
Therefore, in this article, Balázs wrote both his personal feelings and his political stance and a paradox that his "Diary" was written in public symbolizes this mixture. Balázs did not veil his jaundice, jealousy, and sorrow as an old friend. In addition to a personal recollection, this is a farewell to Bartók, who has become a great composer in Europe. This article is a pronouncement of his political stance as a Hungarian exile as well as a farewell to an old friend.

About 16 years later, however, his attitude toward Bartók drastically changed again; Balázs's public letter to Bartók titled "Letters from a Distant Land: Sent to Béla Bartók (Levelek a távolból: Bartók Bélának küldöm)” in 1938. It was published in New Voice (Új hang) in Moscow and the style also changed from diaries to letters. In this letter, he amiably recollected their relationship. This is perhaps partly because Balázs once again reactivated the relationship with Bartók by exchanging letters in Berlin and Moscow. Actually, they met each other in Bartók's concert in Berlin. In this magazine censored by Soviet Republic, Balázs emphasized Hungarian modernism and above all things, admired the cultural policy in Moscow.

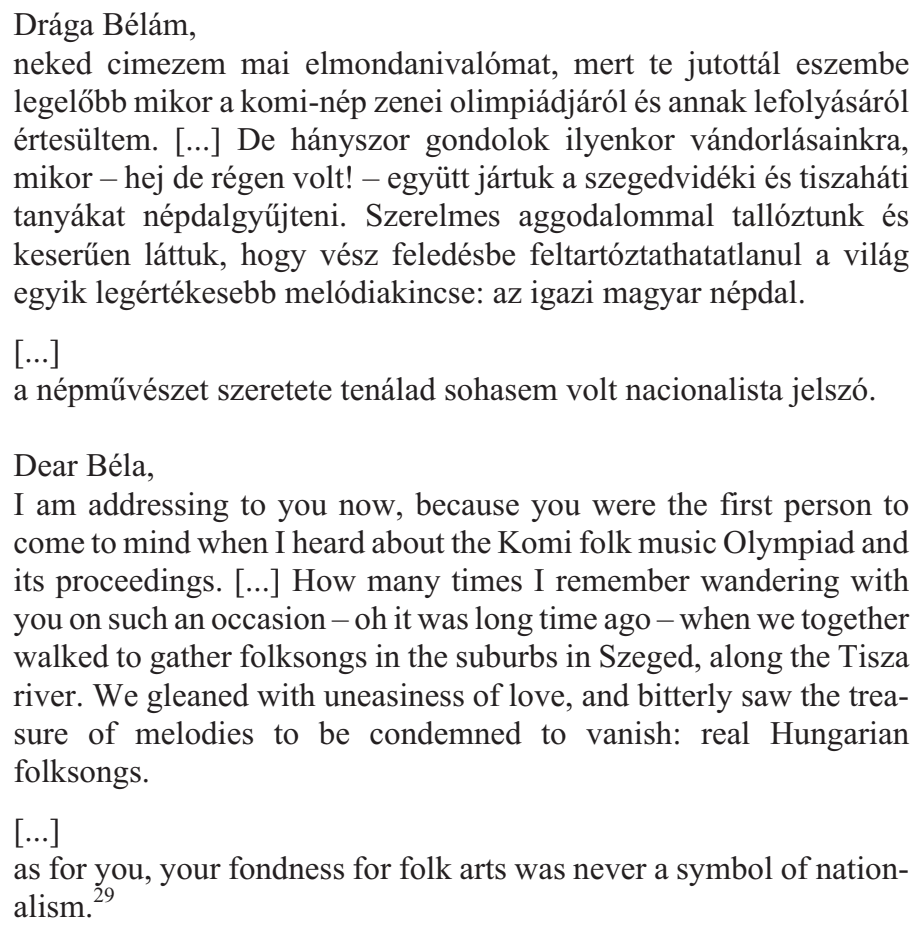

It is Bartók as ethnomusicologist that is emphasized in this article. Balázs wrote about "Folksong Olympiad" as well as Bartók. In the Soviet Republic, varied musicians gathered in Moscow and played folksongs or folk music from all 
over the world. Moreover, he pointed out that they have an affinity with each other, since Bartók collected folksongs from various countries and regions. According to this article, Bartók was not a nationalist composer, but rather a cosmopolitan and international one.

Balázs wrote another letter to Bartók from Moscow: "From Distant Land, to Distant Land", seemingly the most famous recollection written by Balázs. Although it is not clear when and in which magazine or newspaper it was published, its long recollection was prepared for Bartók's $60^{\text {th }}$ birthday in 1941. It was after his departure that Balázs wrote this letter. Although I do not examine its text here because it includes overlap with "Diary" and "Memories of Béla Bartók" analyzed in the following section, it seems that Balázs not only emphasized his achievement of creation of their stage works, but also strongly cherished his adolescence in Budapest and interactions with Bartók. He also mentioned his astonishment about Bartók's emigration and his new lilbretto for another stage production.

With all these texts, a temporal conclusion might be stated. Balázs's recollections written in exile when he was almost shut out from communications with people in Hungary tended to be an activity of cherishing his Budapest period. At the same time, he also took on a political attitude.

\section{Imagined Memories of the Deceased Composer}

The images of Bartók appeared again in Balázs's articles after the death of Bartók in New York. At that time, Balázs had already returned to Budapest and worked as a film director and pedagogue. On October $3^{\text {rd }}$ in 1945, Balázs published a special issue on Bartók in the art magazine Fényszóró, which Balázs edited in 1945-1946 (Figure 2). In addition to Balázs, Kodály, Viktor Lányi, and László Márkus contributed to this issue.

Balázs continued writing about Bartók almost until he died. The most literary recollection among them may be "Indivisible Man (Oszthatatlan Ember)" that appeared in Forum in 1948. This article includes various fragments of his memories of Bartók, and he linked them together one after another. While the image of Bartók appears quite vividly in each episode like a scene of film, it seems to be no more "memories", but created fictions.

To analyze these images, I give an example in this section. Excerpts of "Indivisible Man" are cited as follows. This text is about the creation of the opera Bluebeard's Castle, the first collaborative work between Balázs and Bartók. Balázs recollects an impressive episode when Bartók composed the opera secretly and surprised Balázs by playing the opera's piano reduction version at home. 
Egyszer berohan hozzá Márta. Lángvörös arccal, nedvesen csillogó szemekkel. Minden ajtó tárva maradt mögötte. Két kezét nyújtva felém futott

“Jöjjön! Jöjjön” - ujjongott. Megragadta kezemet, felrántott az íróasztal mellől, húzott kifelé, futva. Tárva maradt minden ajtó. És át a szomszéd Bartók-lakásba. - "Jöjjön! Jöjjöon"

"Mi történt?" - kérdeztem csodálkozva.

"Majd meglátja!" - sugárzott rám boldogan és megindultan. "Béla megtiltotta, hogy szóljak. Meglepetés!

Édes szorongás markolta meg szívemet. Nem sejtettem, hogy mi lehet. De nagy boldog esemény. Délelött tizenegy óra volt, mikor beléptünk Bartók szobájába. Akkor becsukta mögöttünk az ajtót. Márta gondosan és ünnepélyesen csukta be. Ránk is zárta.

Béla a zongora előtt ült, a kótatartón kézirat. Csak egy szemernyi pillanatig villant rám szemüvege mögül tekintete, de olyan mosolygó gyöngédséggel, hogy odaadtam volna érte minden szerelmeket. Aztán hegyes profilját a kótának szegezte.

"Mi történt? - kérdeztem és torkomat már fojtogatta a megindultság holott valóban nem tudtam még.

"Hát történt... valami - felelte a kótába elmondhatatlan kokett szigorúsággal.

"Ide üljön! - nyomott Márta a diván sarkába és hallgasson. Most készült el. Egy félórával ezelőtt."

"Mi?" - leheltem elfulladtan. Bartók belecsapott a zongorába. Eljátszotta nekem a "Kékszakállu herceg várát", mely egy félórával azelőtt készült el.

$[\ldots]$

One day Márta [Bartók's first wife] rushed to me with a red face like a fire and shining, moist eyes. Behind her all the doors were opened. Stretching out both hands, she ran toward me.

"Please, please come!" - she rejoiced. She took my hands, pulled me up from the desk and rushed to draw me out (all the doors were left open) and toward neighbouring Bartók's house. - "Please, please come!"

"What's happened?" - I asked her surprisingly.

"You will see soon." - Her face shined happily with deep emotion. - "Béla forbade me to tell you. It's a surprise!"

Sweet uneasiness tugged at my heart. I couldn't guess what was happening. But it woud be a great, happy event. It was 11 o'clock in the morning when we entered Bartók's room. Then she shut the door 
behind us. Márta carefully and solemnly closed the door. She moved in front of us.

Béla was sitting down in front of the piano and there was a manuscript music sheet on it. For just a moment his glance blinked through his spectacles, but it was with smiling gentleness, as if I gave him all of my affection. Then he fixed his sharp profile to the sheets.

"What's happened? - I asked. My deep emotion had choked my throat though I really still did not know what this was.

"Well, something... has happened. - He replied into the music sheets with unspeakable koketish strictness.

"Please have a seat here! - Márta pushed me to the corner of the sofa - and listen. It has just now been completed - just a half hour ago."

"What?" I took a deep breath with difficulty. Bartók struck the piano. He played for me "Bluebeard's Castle", which had been completed just a half hour ago. [... $]^{30}$

Nevertheless, this story seems to be apocryphal: according to the facts of this opera's creation, their residences in 1911, and their letters or Balázs's diary, such a situation might have been impossible for them. ${ }^{31}$ Namely, it is likely an imagined story by Balázs. Although it is not correct to conclude that these episodes are all fictions, Balázs seems to be quite eager to make these events dramatic.

On the one hand, Balázs created memories; on the other hand, the intertextuality from the composition itself is found in these recollections as well: in terms of content, this episode is not mere memory; it seems that it was written under the influence of the opera's texts. The underlined part of the cited texts include an obstinate repetition of "Doors", "open", and "close". In Bluebeard's Castle, the protagonists Bluebeard and his wife Judith open seven doors in the castle to cast a light, which eventually exposes Bluebeard's nature symbolically and ends with failure. The phrase "open the doors" is reminiscence of texts in the opera itself. This emphasis becomes clear when comparing a variety of this text. Indeed another recollection "Memory" (see Table 2) also records the same episode, but in this version there is no repetition of the phrase "open the doors" ${ }^{32}$ Compared between two versions, he seemed to add this phrase in order to make this scene more vivid and evoke the plot of the opera. This "memory" does not only consist of historical events and fictions. It also includes an intertextuality with the libretto of the opera, entirely fictional composition.

Now we can pose one question: Is it a memory, just a fiction, or a literary work? Indeed Balázs also attempted to answer this question. As mentioned before, "Indivisible Man" was published in Forum, but when it appeared some parts of the texts were deleted from manuscripts and typewritten papers. Actually, the title "Indivisible Man" was originally derived from the deleted section's title. Some 
parts of the abbreviated section are cited in below. This time Balázs emphasized the monumented image of Bartók and the political interpretation of his emigration to the U.S.

Hát ezt nevezzük-e emlékezésnek? A lélek, melyet ő termékenyitett meg, őt akarja ujra világra hozni. Csodálatos mithos hasonlata ez. [...] Irás ez még, vagy szellemidézés? A toll megállna kezemben. De feltámadás történik, megállithatatlanul.

$[\ldots]$

Bartók Béla ugyanis politikai emigráns volt. Ez a legtalajhozkötöttebb müvész kitépte éltető gyökereit a Magyar földből és idegenbe bujdosott azért, hogy tiltakozzék Horthy Magyarországának sötét reakciója ellen. Nem csak egy irással, nem csak egy cselekedettel, hanem egészéletével és halálával tiltakozott.

Well, do we call it "memory" or not? The soul that he [Bartók] made fertile wants to draw him to the world again. This is miraculous mythical imagery. [...] Still, is it writing or necromancy? A pen would like to stop in my hand. But resurrection has started, unstoppably.

$[\ldots]$

Bartók Béla was a political emigrant also. This artist, who was most unseparatable to the land, tore his nurturing roots from Hungarian soil and emigrated abroad to protest the dark reaction of Horthy's Hungary. He protested by not only writing, not only one action, but throughout his whole life and death. ${ }^{33}$

In this section, two significances can be pointed out; the first is an attitude to reinterpret Bartók's emigration politically. According to Balázs, Bartók opposed to Horthy regime and protested so that he had gone to the U.S. This image is absolutely adverse interpretation of an article in 1922. The second is that Balázs himself admitted that it is no more "memories" but his necromancy, namely it is a process of recalling Bartók and embodying him again by writing with his pen. In this article Bartók is not just his friend, but a canonized great composer. At the same time this canonization is so personal that Balázs could also emphasize the friendship with Balázs himself. In this way the double images of Bartók were produced in a series of recollections written by Balázs.

\section{Conclusion}

In this paper, the interactions and the depictions of friendship between Bartók and Balázs were analyzed. Their actual relationship lasted about 10 years or so, and it 
created precious memories for Balázs not only while he was in exile, but also long after his return to Budapest. As described in section 2, Balázs's text varies from recollections to literary works. In the early $20^{\text {th }}$ century, Balázs kept a diary, which includes his personal impression of Bartók. These texts of course remain very private documents, although some public documents show Bartók stating what inspired his literary works. The drastically changing political situation, however, forced Balázs to escape from his homeland and significantly changed their relationship. It is after the exile when Balázs began to write recollections about Bartók.

As discussed previously, for Balázs, writing about Bartók was an attempt to bring him back to Hungarian modernism and give Balázs himself affirmation of his activities in Hungary. At the same time, Balázs's situation as a refugee led him to consider his political stance; therefore, the images of Bartók are quite inconsistent. At any rate, this imagined friendship is actually one-sided, and by adapting not criticism but recollections and public letters, he emphasized his relationship with Bartók. This tendency continued after his return, but Bartók's death influenced Balázs so strongly that the image of Bartók became imagined and canonized. This canonization is a natural means for Balázs to connect with Bartók

Although these recollections are not entirely credible, it is not necessary to consider all of them unworthy of examination, because to some extent Balázs related true facts, including their residences. Therefore, these texts continue to contribute to Bartók's study, especially two stage works produced with Balázs. Moreover, Balázs's texts still remain unpublished. Balázs's study gives a new aspect of his creation - an intertextuality between recollections as autobiography and his stage works. The relation between his political situation in each period and the content of his writing should be examined in more details in future studies.

We could consider these texts as one of the social phenomenon in broader contexts, too. The varied images of Bartók appeared not only in musical culture in the cold war, as Fosler-Lussier shed light, ${ }^{34}$ but also in political and literary culture even during his life. Balázs's recollection shows how the images were used, sometimes distorted and created literally. While Bartók himself was remembered as "Indivisible Man" by Balázs, his images were always "divisible" ones.

\section{Appendix}

\section{Excerpts from Recollections of Béla Bartók [Emlékezés Bartók Bélára]}

Emlékezés az szellemidézés. De nem mi idézünk halottakat. Mert a ami valóban elmult, azt se memoria, de krónika, sem mágia eleveniteni nem tudja többé. Ám van feltámadás. Igen: támadás! 
Ránk támad az emlékezés. Bizony nem mi emlékezünk. Emlékeztetnek magunkra konokul és hevesen, akik öntudatunk alsó kriptáiból ki támadnak, mikor a valóság materiális erői megérlelték az ő idejüket.

Eljött az ő idejük, de nem "magától". Nem az ő mindenütt lappangó hivásuk nélkül. Ök emelik a hantot, ők emlékeztetnek magukra, ők idéznek és feltámadnak.

Nem, nem méla andalodás az emlékezés. Ha döntő rohamra indulunk jövőnkért, akkor Csaba utján segitségünkre száguldó szellemi őseink támadnak a mi támadásunkkal. Feltámadnak.

Ime, eljött Bartók Béla ideje. Emlékezzünk reá? Tekintsetek ma körül a Dunavölgyében és próbáljatok nem emlékezni Bartók Bélára, mikor minden nap uj diadala az ő nevét is hirdeti.

De nemcsak Bartók Béla immár ezmévé vált szellem támadt fel támadón, hanem alakká inkarnálódott szelleme is, mely itt járt közöttünk és szemekkel nézett ránk, hanggal szólitott bennünket és mozdulattal intett felénk. A barát és költő evvel jár lelkében mint magzatával a terhes asszony, immár negyven esztendeje. Hát ezt nevezzük-e emlékezésnek? A lélek, melyet ő termékenyitett meg, ôt akarja ujra világra hozni. Csodálatos mithos hasonlata ez. Magában is lehet feladata és értelme egy életnek. Irás ez még, vagy szellemidézés? A toll megállna kezemben. De feltámadás történik, megállithatatlanul.

\section{Oszthatatlan ember.}

Kezdjük a végén. Mert mártiroknak a halála az, mely visszafelé értelmezi életük minden dolgát. Ezt mindig tudjuk és el ne felejtsük, hogy Bartók Béla nem egyszerüen elhunyt, hanem mártirhalált halt. Még pediga [sic] mi mártirunk ő, mert a Magyar demokrácia harcos eszméjének halottja.

Bartók Béla ugyanis politikai emigráns volt. Ez a legtalajhozköttöttebb müvész kitépte éltető gyökereit a magyar földből és idegenbe bujdosott azért, hogy tiltakozzék Horthy Magyarországának sötét reakciója ellen. Nem csak egy irással, nem csak egy cselekedettel, hanem egész életével és halálával tiltakozott.

Mert ez volt Bartók Béla lényeges jellemvonása: minden meggyőződéséből levonta a végső konzekvenciát, nemcsak gondolatban, nemcsak müvészetében, hanem totálisan, egész életével, fizikai létével is. Soha ilyen egydarabból való, oszthatatlanul monolit embert!

Mert nincsen abban kétség, hogy Bartók Béla abba halt bele, hogy hazáját kellett elhagynia. Nem hiszünk misztikus erőkben. Tudjuk, hogy Bartókot sulyos betehség [sic] vitte sirba. De azt is tudjuk, hogy máskép emészti a kór azt, aki számkivetve és keserü lélekkel, müvészetének talaja nélkül sinylődik és reménytelen magányban, mint azt, aki testileg-lelkileg otthon van.

De Bartók Béla mindent végig csinált. Fenntartás és megalkuvás nélkül, maniakus, aprólékos pedantériával. Nem volt napja, napjának órája, melyben nem 
lett volna egészen Bartók Béla. Egész egyéniségének vértezetében élt szüntelenül. A groteszk paradoxiákig.

Valami programmatikus és stilizált lehetett volna ebben a magatartásban, ha egy pillanatra is szándékoltnak látszott volna. De a sorsszerü kényszer félelmek fátuma érzett rajta. Nem tudott máskép. Az elkerülhetetlen, feltarthatatlan szükségszerüség tették monumentálissá legkisebb mozdulatát, leghalkabb hangsulyát is. Gyakran merev volt ezért. Rideg. Valóban. De szikla. Nemcsak hajlithatatlan, hanem törhetetlen is.

Remembrance is necromancy. But we don't summon the dead, because any memories, chronicles, or magic can revive no more what has really passed away. Yet there is a resurrection [feltámadás]. Indeed: an attack! [támadás]

Memories attack us. Certainly we do not remember. They make us remember, severely and violently, who attack from the crypt of our consciousness when the material power of reality returns us to their time.

Their time has come, but it is not "by themselves". It is not without their ubiquitous hidden calling. They dig the grave, they reminded us of themselves, and they call and summon themselves.

Recollection is not a lulling dream. If we so hurry towards our future then our spiritual ancestors meet our attack, rushing to call our help in Csaba's way. They summon themselves.

Here Bartók's time has come. Shall we recollect him? Please take a glance around today in the Duna valley, and do not remember Béla Bartók when they give new glory to his name every day.

But it is not only Béla Bartók's soul revives on arising, which has already manifested as conceptual, but also his soul revives, which has incarnated to the body. His soul goes around between us, look at us with its eyes, call us with its voice, and with its movement it signals us. The friend and the poet have already interplayed in the soul in this way for 40 years, like a pregnant woman and her baby. Well, do we call it "memory" or not? The soul that he [Bartók] made fertile wants to draw him to the world again. This is miraculous mythical imagery. There might be a problem and meaning for a life in himself as well. Is it yet writing or necromancy? A pen would like to stop in my hand. But resurrection has started, unstoppably.

\section{Indivisible $\operatorname{Man}^{35}$}

Let us start from the end. It is because it is a martyr's death that we interpret everything backwards in his life. We always know it, and we shall not forget that Béla Bartók did not merely die, but died a martyr's death. He is still our martyr, because he is a deceased fighting spirit of Hungarian democracy. 
Bartók Béla was a political emigrant, also. This artist, who was most unseparatable to the land, tore his nurturing roots from Hungarian soil and emigrated abroad to protest the dark reaction of Horthy's Hungary. He protested by not only writing, not only one action, but throughout his whole life and death.

It is because this was Béla Bartók's essential characteristic: he drew a final conclusion from every conviction not only in his thought, not only in his arts, but also with his whole life and physical existence. I have never seen such a man who consists of one piece, an indivisible monolith!

It is obvious that Béla Bartók died because he had to leave his country. We do not believe in mystical power. We know that serious disease brought Bartók to the grave. But we also know that a sickness undermines a person in other ways who exiled and languishes, with bitter feeling and without ground of arts in hopeless loneliness, than one is at home physically and spiritually.

But Béla Bartók always did everything thoroughly, without reservation or compromise, maniacally, in meticulous detail. There were no days, nor hours of the day, in which he would not be completely Béla Bartók. He stood complete in the armor of his personality unceasingly. Till the paradox of grotesque.

There could have been an element of conscious attitudinizing in this posture, if for even a moment it had appeared intentional. But the relentless and inescapable force of fate was to be sensed in it. He could not do in other ways. The inevitable and unstoppable necessity altered his slightest movement and the most silent stress to monumental ones. Thus, he was often rigid. Cold. Indeed. He was a rock. He was not only inflexible, but also unbreakable.

\section{Notes}

Júlia Lenkei, 'Nívómbelivel együtt dolgozni...': Balázs Béla két szövegkönyve. Criticai Lapok, 7-8 (2009), http://www.criticailapok.hu/index.php?option=com_content\&view=article\&id=37702\&catid=15\&Itemid=2 (Accessed: 29 January, 2013).

2 The list of the collection is included in Dóra F. Csanak, Balázs Béla hagyatéka az Akadémiai Könyvtár Kézirattárában (ms 5009-ms 5024) (Budapest: Bibliotheca Academiae Scientiarum Hungaricae, 1966).

3 I greatly appreciate the help provided by the librarians in the Manuscript Collection in Széchényi Library for suggesting these unpublished resources. Josef Zsuffa also mentioned in the bibliography that Balázs's unpublished librettos are stored in Széchényi Library, although he did not show exactly where they are. See Josef Zsuffa, Béla Balázs: The Man and the Artist (Berkeley: University of California Press, 1987), 515.

4 János Demény, Adatok Balázs Béla és Bartók Béla kapcsolatához. In Magyar zenetörténeti tanulmányok: Kodály Zoltán emlékére, edited by Ferenc Bónis (Budapest: Zenemúkiadó, 1977), 373.

5 Carl S. Leafstedt, Inside Bluebeard's Castle (New York: Oxford University Press, 1999), 31.

6 Zsuffa took over the texts of Dreaming Youth in the beginning of the biography. Although it is not strictly a biography, Mary Gluck also cites Impossible People to explain Balázs's life. See 
Mary Gluck, Georg Lukács and His Generation, 1900-1918 (Cambridge, MA: Harvard University Press, 1985).

7 This aspect will be discussed in Section 3 in this paper.

8 Béla Balázs, Napló: 1903-1914, by Anna Fábri, vol. 1 (Budapest: Magvető Kiadó, 1982), 339. This text will be discussed in Section 3.

9 The building in which Bartók and Balázs lived is located today in the place of Teréz ringstreet 22. The photo of this building is inserted in Ferenc Bónis, Béla Bartók: His Life in Pictures and Documents (Budapest: Corvina, 1980), 91. This old address (Teréz ringstreet 17) is identified as an erroneous building (at that time Teréz ringstreet 13 and today 17), in Lynn Hooker, The Political and Cultural Climate in Hungary at the Turn of the Twentieth Century, in The Cambridge Companion to Bartók, edited by Amanda Bayley (Cambridge: Cambridge University Press, 2001), 21. It is important to note that house numbers have been changed frequently. I am grateful to Prof. Shingo Akiyama at Hitotsubashi University, who kindly advised and provided me with the map of old Budapest.

10 It is known that Bartók and his mother lived in this residence from November $1^{\text {st }}$ in 1907 to May $3^{\text {rd }}$ in 1911. See Béla Bartók Jr., Apám életének krónikája (Budapest: Helikon Kiadó, 2006), 97, 121, and Bartók to János Bușiția, 27 April, 1911, Bartók Béla levelei, edited by János Demény (Budapest: Zenemúkiadó, 1976), 178-9. Moreover, Balázs's letters show that he also lived in that building at least from January $4^{\text {th }}$ to September $26^{\text {th }}$. See Balázs to György Lukács, a letter and its envelope, 4 January, 1910, Georg Lukács Archives of the Institute for Philosophical Research, 85/2, the Hungarian Academy of Sciences, and Balázs to Mihály Babits, 26 September, 1910, Manuscript Collection, National Széchényi Library. I greatly appreciate the help given by Mária Székely (Lukács Archives), who sent me these envelopes.

11 Balázs mentioned that he was going to write librettos for Kodály and Bartók when he sent Bartók the revised texts of Bluebeard's Castle, saying "I don't forget your one-act grotesque pantomime. I'm sure it will be [produced]". Béla Balázs to Béla Bartók, ca. beginning of 1912, Bartók Archives of Institute for Musicology of the Research Centre for the Humanities, the Hungarian Academy of Sciences.

12 Béla Balázs, Napló: 1903-1914 I, 606.

13 Béla Balázs, Napló: 1903-1914 I, 610. See also Demény, Adatok Balázs Béla és Bartók Béla kapcsolatához, 364.

14 Demény, Adatok Balázs Béla és Bartók Béla kapcsolatához, 364.

15 Béla Balázs, Dramaturgia. Előadások a Szellemi Tudományok Köréből 2 (Budapest: Benkő Gyula Cs. és Kir. Udvari Könyvkereskedése, 1918), 44-5.

16 Antal Molnár summarized several critics about the premier of Bluebeard's Castle in Zenei Szemle in August 1918. According to his article, some of them said, "the texts with no action entirely killed the potentiality of music". Zita Burda and Dániel Kis Domokos, eds., Bartók a szinpadon (Budapest: Osiris, 2006), 78.

17 Tibor Tallián, Béla Bartók: the Man and his Work (Budapest: Corvina, 1981), 116-20 and Zsuffa, Béla Balázs, 78-84. Lukács was the deputy of this comissariat.

18 Balázs to Bartók, November 1930, Bartók Archives of Institute for Musicology of the Research Centre for the Humanities, the Hungarian Academy of Sciences. See also Zsuffa, Béla Balázs, 188.

19 László Somfai introduced this libretto in Nichtvertonte Libretti im Nachlass und andere Bühnenpläne Bartóks, in Documenta Bartókiana, Heft 2, edited by Denis Dille (Mainz: B. Schott's Söhne, 1965), 29-30. Lenkei and Zsuffa also stated that the libretto sent to Bartók is likely this pantomime. See Lenkei, 'Nívómbelivel együtt dolgozni...:' Balázs Béla keìt szövegkönyve, and Zsuffa, Béla Balázs, 188. 
20 Hooker, The Political and Cultural Climate in Hungary at the Turn of the Twentieth Century, 21.

21 The inclination to create "new Hungary" by introducing contemporary western European culture is parallel to that of Lukács, founding Thália Society in the field of dramas in 1904-08. As for New Hungarian Music Society and Hungarian modernist movement. See Judit Frigyesi, Béla Bartók and Turn-of-the-Century Budapest (Berkeley: University of California Press, 1998) and Lynn Hooker, Modernism on the Periphery: Béla Bartók and the New Hungarian Music Society of 1911-1912, Musical Quarterly 88, 2(2005), 274-319.

22 Béla Balázs, Napló: 1914-1922 II (Budapest: Magvető Kiadó, 1982), 461.

23 Béla Balázs, Napló: 1903-1914, 339. The translation was largely taken over from Leafstedt, Inside Bluebeard's Castle, 17-18.

24 Balázs, Napló: 1903-1914, 510-13. The translation was largely taken over from Leafstedt, Inside Bluebeard's Castle, 27 and László Vikárius, Commentary to Béla Bartók Duke Bluebeard's Castle, in Duke Bluebeard's Castle, Opus 11: Facsimile of the Autograph Draft, edited by László Vikárius (Budapest: Balassi Kiadó, 2006), 21.

25 Béla Balázs, A zenei szépség evoluciójáról, Színjáték, 15(1910): 288-91.

26 Béla Balázs, Napló, Bécsi Magyar Újság, 1922, May 21, 8. The translation was largely taken over from Leafstedt, Inside Bluebeard's Castle, 23-5.

27 Noriko Tsujikawa, Bōmeisha ni yoru Pari kōwa kaigi shuō no Chū-Tō $\bar{O}$ no kokusai taisei e no taian: Pēchi deno Yūgo gun senryō keizoku yōkyū undō wo megutte (1919-1921 nen) [An Alternative by Hungarian 'Exiles' to the International Order under the Paris Peace Conference in Central and Eastern Europe: The Significance of the Requests from Pécs for the Extension of Occupation under SHS (1919-1921)], Tō Ō shi kenkyu [The Journal of East European Studies] 35(2013), 75. Balázs's wife Anna Hamvasy worked in its office as a typist.

28 Béla Balázs, Napló, Bécsi Magyar Újság, 1922, May 21, 8.

29 Béla Balázs, Levelek a távolból, Új hang, 4(1938), 97, 100.

30 Béla Balázs, Emlékezés Bartók Bélára, Department of Manuscripts \& Rare Books, Library of the Hungarian Academy of Sciences, MS 5014/38. Translated by the author of this paper.

31 I supposed so for several reasons: first, there are no such entries in his diaries; second, it is not likely that Bartók finished composing the opera when they lived in the same building. The creation of Bluebeard's Castle has already been examined in Leafstedt and Vikárius. Bartók started to compose the opera in February in 1911 and moved to Rákoskeresztúr on May $3^{\text {rd }}$. Moreover, Bartók wrote to Frederick Delius that he had not finished yet in July and to his wife Márta Ziegler in 1915 that he could not even play this opera on the piano. See Leafstedt, Inside Bluebeard's Castle, 127-35 and Bartók to Márta Ziegler, 1915, Bartók családi levelei, edited by Béla Bartók Jr. (Budapest: Zenemúkiadó, 1981), 236.

32 Béla Balázs, Emlékezés, Department of Manuscripts \& Rare Books, Library of the Hungarian Academy of Sciences, MS 5014/39. It seems that this short text was prepared for the performance of Bluebeard's Castle.

33 Balázs, Emlékezés Bartók Bélára.

34 Danielle Fosler-Lussier, Music Divided: Bartók's Legacy in Cold War Culture (Berkeley: University of California Press, 2007).

35 This part was partly published as an introduction of Béla Balázs, Indivisible Man, Forum, December 1948, 956-65. The translation was partly taken over from Tallián, Béla Bartók, 13. 